\title{
Some Recent Decisions Involving Federal Land Patents
}

A

TTEMPTS are being made constantly to break down the force and effect of patents issued by the United States for its public lands. The courts have quite consistently refused to encourage these attacks and have gradually by a long line of decisions fortified the conclusive effect of the government's conveyances, until land patents issued by the United States have become clothed with a dignity and character which render them immune from most of these attempts to destroy their integrity. ${ }^{1}$

The tendency of the courts is to further strengthen the effect of patents rather than to relax. This subject has recently assumed greater interest than usual because of several decisions which have just been rendered by the Supreme Court of the United States and by the Circuit Court of Appeals bearing on this subject. Most of these cases were suits brought by the government itself to have its own patents set aside and were the outcome of the more rigorous surveillance on the part of the government in parting with title to its public lands in pursuance of the conservation policy which has recently taken such firm root.

Probably the most important case of this character which has arisen in many years is what is commonly known as the Burke case. $^{2}$ This case arose in the oil fields of California and was an attempt on the part of Burke and others to assert rights claimed to have arisen by virtue of placer mining locations made on valu-

1 St. Louis Smelting Co. v. Hemp (1881), 104 U. S. 636, 26 L. Ed. 875; Steel v. St. Louis Smelting Co. (1882), 106 U. S. 447, 27 L. Ed. 226, 1 Sup. Ct. Rep. 389; Maxwell Iand-Grant Case (1886), 121 U. S. 325, 30 L. Ed. 949, 7 Sup. Ct. Rep. 1015; Barden v. Northern Pac. R. R. Co. (1894), 154 U. S. 288, 38 L. Ed. 992, 14 Sup. Ct. Rep. 1030; Shaw v. Kellogg (1898), 170 U. S. 312, 42 L. Ed. 1050, 18 Sup. Ct. Rep. 415, are leading cases which illustrate this development.

2 Burke v. So. Pac. R. R. Co. (June 22, 1914), 234 U. S. 669, 34 Sup. Ct. Rep. 907. The decision in the trial court is not reported, but demurrers were sustained and a decree entered dismissing the bills, for reasons assigned in an opinion announced the same day in Roberts v. So. Pac. R. R. Co., 186 Fed. 934. 
able oil lands previously patented to the railroad company under its land grant. While only five sections of land were involved, this was a test case and the determination of the questions presented directly affected similar lands patented to the railroad coinpany having a value that. was commonly reported to be over half a billion of dollars. The suit, though brought by private individuals, raised several important questions in which the government was vitally interested by reason of the fact that it was contemplating bringing direct proceedings for the annullinent of similar railroad patents, and hence it was ably represented by counsel detailed from the federal Department of Justice. The case was appealed to the Circuit Court of Appeals (Ninth Circuit) but this court, in view of the gravity of the problems and the magnitude of the interests involved, certified the case to the Supreme Court of the United States for instruction upon designated questions of law. ${ }^{3}$

The questions propounded in the certificate were as follows:4

I. Did the said grant to the Southern Pacific Railroad Company include mineral lands which were known to be such at or prior to the date of the patent of July Ioth, I894?

Answer.-Mineral lands, known to be such at or prior to the issue of patent, were not included in the grant, but excluded froin it, and the duty of determining the character of the lands was cast primarily on the Land Department, which was charged with the issue of patents.

2. Does a patent to a railroad company under a grant which excludes mineral lands, as in the present case, but which is issued without any investigation upon the part of the officers of the Land Office or of the Department of the Interior as to the quality of the land, whether agricultural or mineral, and without hearing upon or determination of the quality of the lands, operate to convey lands which are thereafter ascertaimed to be inineral?

Answer.-A patent issued in such circumstances is irregu-

3 This procedure is authorized by $\S 239$ of the Feteral Judicial Code (36 Stat. at L. 1157).

4 In order to secure the advantage of juxtaposition, the specific answers made by the Supreme Court to each of these certified questions is inserted after each respective question. 
larly issued, undoubtedly so; but, as it is the act of a legally constituted tribunal, and is done within its jurisdiction, it is not void, and therefore passes the title (Noble v. Union River Logging R. Co. (1892), I47 U. S. I65, I74, I75, 37 L. Ed. 123, I26, I27, I3 Sup. Ct. Rep. 27I), subject to the right of the government to attack the patent by a direct suit for its annulment if the land was known to be mineral when the patent issued (McLaughlin v. United States (I882), I07 U. S. 526, 27 L. Ed. 62I, 2 Sup. Ct. Rep. 862; Western Pac. R. R. Co. v. United States (I882), I08 U. S. 510, 27 L. Ed. 806, 2 Sup. Ct. Rep. 802).

3. Is the reservation and exception contained in the grant in the patent to the Southern Pacific Railroad Company void and of no effect? void.

Answer.-The mineral land exception in the patent is

4. If the reservation of mineral lands as expressed in the patent is void, then is the patent, upon a collateral attack, a conclusive and official declaration that the land' is agricultural, and that all the requirements preliminary to the issuance of the patent have been complied with?

Answer.-It is conclusive upon a collateral attack.

5. Is petroleum or mineral oil within the meaning of the term "mineral", as it was used in said acts of Congress reserving mineral land from the railroad land grants?

Answer.-Petroleum lands are mineral lands within the meaning of that term in railroad land grants.

6. Does the fact that the appellant was not in privity with the government in any respect at the time when the patent was issued to the railroad company prevent him from attacking the patent on the ground of fraud, error, or irregularity in the issuance thereof as so alleged in the bill?

Answer.-It does.

7. If the mineral exception clause was inserted in the patent with the consent of the defendant, Southern Pacific Railroad Company, and under an understanding and agreement between it and the officers of the Interior Department that said clause should be effective to keep in the United States title to such of the lands described in the patent as were in fact mineral, are the defendants, Southern Pacific Railroad Company and the Kern Trading \& Oil Company, estopped to deny the validity of said clause? 
Answer.-No; such an agreement is of no greater force as an estoppel than the exception in the patent. The latter being void, the patent passes the title and is not open to collateral attack, or to attack by strangers whose only claim was initiated after the issue of the patent.

The Supreme Court in its opinion written by Justice Van Devanter ${ }^{5}$ first disposed of the fifth question, holding that petroleum in its ordinary and popular sense was a mineral and that Congress in excluding "mineral lands" from the operation of the railroad granting act, was "dealing with a practical subject in a practical way" and "doubtless the ordinary or popular signification of that term was intended".

The court then proceeded to discuss collectively several of the other questions involved, deciding that the railroad granting act expressly provided for the issue of patents to the lands granted; that this function was confided to the Land Department under the general law in force and therefore, it devolved upon the department to identify the lands to be patented, as obviously the lands expressly excluded by the terms of the grant were not to be so patented; that it necessarily followed that the power and duty of determining in every instance whether or not the land was subject to patent, rested with the department; that the mineral exclusion clause is not peculiar to railroad lands, but appears in the homestead, desert-land, timber and stone, and other public-land laws and in each instance the character of the land is a question for the Land Department just as are the qualifications of the applicant and his performance of the acts prerequisite to the patent's issuance; that a railroad patent when once issued has all the force and effect of patents issued under these other public-land laws and upon collateral attack it affords "conclusive evidence of the non-mineral character of the land and of the regularity of the acts and proceedings resulting in its issue, anl upon a direct attack. . . [it affords] . . such presuinptive evidence thereof as to require plain and convincing proof to overcome it."

The court then took up the question of the validity of the clause inserted in the patents by the Land Department as a precautionary measure, viz: "excluding and excepting from the trans-

5234 U. S. 669 , at p. 676,34 Sup. Ct. Rep. 907 , at p. 910. 
fer by these presents all mineral lands, should any sucit be found to exist in the tracts described in this patent". It was insisted by those opposing the railroad title that this clause indicated that the Land Department did not consider and determine whether the lands were mineral or not and that even lands discovered to be mineral after the issuance of patent should be excepted from its operation. The court, however, called attention to the fact that the circulars, procedure and decisions of the Land Department all indicated that it "regarded the issuing of such a patent as a determination of the non-mineral character of the land, and as effectually and unconditionally passing the title" and that the excepting clause had been expressly held by the Secretary of the Interior "as without any warrant in law and void". ${ }^{\circ}$ Several decisions of the courts holding invalid similar attempts on the part of the land departinent to qualify various kinds of patents to public lands were cited and the conclusion reached that these decisions established a rule of property which had become impregnable.

The contention that Congress had placed the grant under consideration in a distinct category by providing in a special resolution enacted later that all the odd-numbered sections within the primary limits of the grant should be patented, and that it was contemplated that this should be done without any inquiry as to their occupancy or mineral character, was also held to be unfounded, since Congress could not have intended that the company should receive patents for lands within the primary or place limits and also for additional lieu lands within the indemnity limits. And the more reasonable view was to give effect to those excepting clauses contained in the granting act in a normal and rational way "by patenting to the company no lands occupied by actual settlers or otherwise excluded or excepted from the grant". The fact that the railroad company had accepted patents containing the void excepting clause was urged as a sort of estoppel on the railroad having the effect of preventing it from denying the validity of the exception. The court held, however, that as the patentee had no voice in the matter and the land department was not authorized to insert the exception, the point was not well taken.

That the findings of the land officers in issuing patents are not, however, conclusive upon direct attack by the government and

- Re Northern Pac. R. R. Co., 32 Land Dec. 342. 
that patent application proceedings are not adversary in any true sense as far as the government is concerned is a well established proposition recently re-affirmed. ${ }^{7}$ While the questions of fact essential to the issuance of patents are committed to the land officers for determination, yet it is possible in ex parte proceedings to impose on these officers and by fraudulent proofs secure entries and patents of a nature that the true character of the land does not justify. Such patents are voidable and may be annulled in a direct suit brought by the government against the patentee or a purchaser with notice of the fraud. ${ }^{8}$ The issuance of the patent is treated as being in the nature of a judgment in rem, ${ }^{9}$ and the action of the land officers in issuing the patent, as being presumptively correct ${ }^{10}$ and in attacking the patent the government carries "the burden of proving the fraud by that class of evidence which commands respect, and that amount of it which produces conviction".11

A final question arises as to the length of time within which suit to cancel a patent may be instituted by the government.

The Act of Congress, approved March $3,189 \mathrm{I}^{12}$ provides that suits by the United States to vacate and annul patents thereafter issued must be brought within six years of the date of the issuance of the patent. ${ }^{13}$ The effect of this statute is to validate patents outstanding for six years which might clearly have been set aside on direct attack because of some vital defect in the antecedent proceedings which culminated in the issuance of the patent. The statute presupposes an instrument which might be

7 Washington Securities Co. v. United States (May 25, 1914), 234 U. S. 76, 79, 34 Sup. Ct. Rep. 725, 726.

8 Diamond Coal and Coke Co. v. United States (April 6, 1914), 233 U. S. 236, 34 Sup. Ct. Rep. 506 . One who has acquired such a right to the land as to entitle him to that form of equitable relief, may also bring a suit to have the patentee declared a trustee, Burke v. So. Pac. R. R. Co. (June 22, 1914), 234 U. S. 669, 676, 34 Sup. Ct. Rep. $907,910$. 9 El Paso Brick Co. v. MeKnight (April 6, 1914), 233 U. S. $250,258-260,34$ Sup. Ct. Rep. 498, 501-502. See also note to Hartman v. Warren (1896), 76 Fed. 157,22 C. C. A. 30. 32,34

${ }_{10}$ Mason v. Washington Butte Mining Co. (May 4, 1914), 214 Fed.

${ }_{11}$ Washington Securities Co. v. United States (May 25, 1914), 234 U. S. 76, 34 Sup. Ct. Rep. 725; Diamond Coal and Coke Co. (April 6, 1914), 233 U. S. 236, 34 Sup. Ct. Rep. 506; Connor v. United States (May 4, 1914), 214 Fed. 522, 529.

1226 Stat. at L. $1093, \$ 8$.

13 Burke v. So. Pac. R. R. Co. (June 22, 1914), 234 U. S. 669, 693, 34 Sup. Ct. Rep. 907, 917. 
declared void, for if its operation were confined to valid patents it would be meaningless. ${ }^{14}$ After the statute has run the patent is to have the same effect against the United States that it would have had if it had been valid in the first instance.

Whether or not, in the case of patents where concealed fraud exists, the statute begins to run until the discovery of the fraud is a question upon which there is a marked difference of judicial opinion. Some of the trial federal courts have held that the statute is all-embracing and that suits of every nature including those involving fraud come within its purview, ${ }^{15}$ while the Circuit Court of Appeals has held that the element of concealed fraud tolls the statute until the discovery of the fraud by the United States. ${ }^{16}$ The present weight of authority is naturally represented by these latter holdings, though the question will not be placed at rest until the Supreme Court of the United States has spoken the final word. ${ }^{17}$

San Francisco, California.

William E. Colby.

14 United States v. Chandler-Dunbar Co. (1907), 209 U. S. 447, 450, 52 L. Ed. 881, 884, 28 Sup. Ct. Rep. 579, 580.

15 United States v. Smith \& Werner (1910), 181 Fed. 545, 554; United States v. Exploration Co. (1911), 190 Fed. 405, 406.

${ }_{16}$ United States v. Lee Wilson \& Co. (Feb. 20, 1914), 214 Fed. 630, 649-650; Linn \& Lane Timber Co. v. United States (1912), 196 Fed. 593, 599; United States v. Exploration Co. (1913), 203 Fed. 387; Moses v. Long Bell Lumber Co. (1913), 206 Fed. 51.

${ }_{17}$ There are cases now pending which will probably bring this question flatly before the Supreme Court of the United States for decision. 